\title{
A New Way Forward: Rebalancing the U.S. Security Cooperation with Greece in a Fast Changing Geostrategic Environment
}

\author{
Michail Ploumis ${ }^{1}$ \\ Correspondence: Michail Ploumis, Department of Economics, School of Management and Economics, University of \\ Peloponnese, Tripolis Campus, Greece.
}

Received: December 27, 2017

doi:10.11114/afa.v4i1.2950
Accepted: January 22, $2018 \quad$ Available online: January 24, 2018

URL: https://doi.org/10.11114/afa.v4i1.2950

\begin{abstract}
The Hellenic National Defense Forces (HNDF) modernization is at a crossroads because of the current and persistent Greek economic and fiscal crisis. After WW II until today, Greece benefitted from the U.S. security assistance and cooperation programs. Meanwhile, the Balkans and the Eastern Mediterranean regions geostrategic environment is changing fast to an unpredictable future. That said, Greece, and the U.S.A. under rebalanced approaches, should consider the U.S. security assistance and defense cooperation programs to meet HNDF modernization requirements and current security challenges for both countries in the region. A new framework of cooperation would serve common national security interest of both Greece and the United States in the Balkans and the Eastern Mediterranean regions.
\end{abstract}

Keywords: U.S. security assistance, U.S. security cooperation, Greece, FMFP, FMS, EDA, IMET, SPP, Hellenic Defense Industrial Base

JEL Classification: F35, F52, H56, H57.

\section{Introduction}

Greece is undergoing a multiyear economic and fiscal crisis, which has depressed the economic output by $25 \%$ during the 2009-2016 period, and has severely curtailed governmental spending including that for national security. Since 2010, Greece has been receiving financial support from the European Union (EU) and the International Monetary Fund (IMF) to cope with its fiscal challenges (EC 2010, 2012). In August 2015, Greece agreed to a new program from the EU, which paved the way for new loans of up to $€ 89$ billion (bn.) during the 2015 - 2018 timeframe. Among other provisions, Greece must "reduce permanently [of what they were at that time] the expenditure ceiling for military spending by $€ 100$ million in 2015 and by $€ 400$ million in 2016 with a targeted set of actions, including a reduction in headcount and procurement" (EC 2015, 7). During the 2009-2014 period (2009 is considered the base year of the Greek economic and fiscal crisis), the Government of Greece cut total defense expenditures by half due to fiscal austerity. ${ }^{2}$ In particular, military procurement, research, and development (R\&D) outlays decreased from a high point of $€ 2.17 \mathrm{bn}$. in 2009 to $€ 0.53$ bn. in 2014 or by $75.58 \%$ (not adjusted for inflation).

In July 2017, Greece signed the Supplemental Memorandum of Understanding (SMoU, 2017), which updates the policy conditions set out in the program of August 2015. According to this Memorandum, "The Greek authorities commit to ensuring sustainable public finances by pursuing the fiscal path agreed in August 2015 that is based on primary surplus targets of 1.75 and 3.5 percent of GDP in 2017 and 2018 respectively." Furthermore, the Greek government "will adopt the Medium-Term Fiscal Strategy (MTFS) 2018-21 that will set spending ceilings consistent with ESM programme

\footnotetext{
${ }^{1}$ Michail Ploumis is an officer on active duty with the Hellenic Army. He holds a PhD in the area of national defense economics in Greece form the University of Peloponnese, Department of Economics (2017). He also holds a LL.B (1997), a LL.M (2005) from the Faculty of Law of the National and Kapodistrian University of Athens, and a M.S.S. (2016) from the U.S. Army War College (USAWC). He is currently a post-doctoral researcher at the University of Peloponnese.

The opinions expressed in this article are the author's own and do not reflect positions of the Greek Government or the Hellenic Army.

${ }^{2}$ Source: HMOD. Released to the author by, AD/F.400/3/126980/S.260/January 30 2015/HMOD/GDOSY/DOI/YPEP.
} 
targets and a primary surplus of 3.5\% of GDP for 2019, 2020 and 2021. These will be supported by adopting parametric measures with an expected yield of 0.3 percent of GDP cumulatively through 2018. " Among other measures, the Greek government will adopt "the rationalisation of certain allowances in military sector, yielding 7 million EUR in 2018."

In the near future, by dismissing random events, and focusing on routine patterns, we assume that new procurement programs and R\&D awards for the Hellenic National Defense Forces (HNDF) benefit will be limited to spare parts and limited upgrades of existing weapons systems. Such programs at most will reach approximately $€ 0.5$ bn. per year. The decrease of these programs will negatively affect the modernization of the HNDF in the medium term timeframe. In the near future, the HNDF will have aging equipment with higher maintenance issues and they will lack cutting - edge military technology. This outcome will pose threats to Greek national security and the region's stability. Since the end of WW II, Greece and the HNDF in particular has benefitted from major U.S. security cooperation programs to counter Hellenic national security challenges. Thus, a way to partially address the consequences of reduced funding for defense procurement and R\&D would be the increased use of U.S. security cooperation programs in the future under a new framework of partnership.

Driven by the above facts and assumptions, this paper will briefly refer to the U.S. security cooperation programs and their purposes. It will examine these programs for Greece in the past, as well as Greece's geostrategic position and current national security challenges. Then, it will form some concepts of assisting the HNDF to overcome their financial difficulties in the future for modernization needs by using relevant U.S. security cooperation programs. These concepts will be based on a rebalanced cooperation and partnership between Greece and the United States for meeting both countries common national security interests in the Balkans and the Eastern Mediterranean regions, in this era of the ongoing Greek economic crisis.

\section{Literature Review: Outline the U.S. Security Cooperation}

As Aseltine et al (2016, 1-31) recount, the U.S. security assistance programs have had their roots since the American Revolutionary War. Since WW II, these programs have been institutionalized and have been used to build the U.S. allies and partner capacity and promote U.S. national interests around the globe under the broad term of the U.S. Security Cooperation (Mclnnis \& Lucas, 2015; White, 2014; Freier, 2010). This term includes all the U.S. Department of State (DOS) security assistance programs, and U.S. Department of Defense (DOD) security cooperation programs, which involve security assistance and security force assistance and cooperation administered by DOD under the foundations of U.S. federal law that includes applicable statutes, administrative regulations, presidential findings and directives, etc.

The legal basis for providing the relevant authorizations and appropriations through all levels of the U.S. administration and congressional authorities involves two basic U.S. laws: the Foreign Assistance Act (FAA), and the Arms Export Control Act (AECA) (Kelly et al., 2010). The majority of the programs remain under the control of the DOS while the rest are administered by the DOD (Aseltine et al 2016, 1-1 to 1-30). Major security assistance programs under the control of DOS involve the Foreign Military Sales (FMS), the Foreign Military Financing Program (FMFP), the Direct Commercial Sales (DCS), the Military Assistance Program (MAP), the Excess Defense Articles (EDA), the International Military Education and Training (IMET), and the Economic Support Fund (ESF). Under the broader context of security cooperation, the DOD has been authorized to administer security assistance programs as previously explained. The U.S. armed forces also maintain their own bilateral or multilateral relations with the military forces of other nation-states that include training and equipment programs, defense procurement, humanitarian assistance, combined exercises, contact programs (e.g. the State Partner Program or SPP), peacekeeping, stability, and anti-terrorism operations, etc. ${ }^{3}$

Reveron (2016) in his Exporting security extensively analyses the U.S. security cooperation programs and how they have become a "pillar of [the U.S.] defense strategy," in a fast changing security environment. Under the concept of "help others help themselves," which U.S. Secretary of Defense Robert M. Gates (2010) laid out, the U.S. has been executing numerous security cooperation programs worldwide with remarkable results (e.g. in Colombia (Tickner,

${ }^{3}$ One U.S. DOD contact program that is widely used is the National Guard State Partner Program (SPP) (Aseltine et al 2016, 1-29). This program was initially established to support the post-Warsaw Pact transition of the armed forces of Eastern European countries that also joined NATO, but it has also undergone a global expansion. The SPP partners National Guard units of a particular state within the U.S. with the military forces of a partner foreign nation in a long-term relationship involving training events, emergency management, environmental remediation exercises, fellowship-style internships, educational exchanges, or civic leader visits. Many Eastern European countries took advantage of this program and have established bilateral relationships with National Guard units in designated states within the U.S. (e.g., New Jersey /Albania, Ohio / Hungary and Serbia, Tennessee / Bulgaria, Vermont / The Former Yugoslav Republic of Macedonia, etc.). 
2014), in Mexico (O' Neil 2013), in the Caribbean) (Bowling 2011) etc.). Meanwhile, the United States, Japan and Australia have expanded their existing security cooperation towards a more "dynamic" partnership to rebalance the national security relationships in the Asia - Pacific region towards China (Satake \& Ishihara 2012).

The security cooperation programs advance the U.S. national security goals overseas, and support the projection of American "soft power" worldwide (Nye, 2008). These programs are one of the tools that the U.S. uses to build partnerships with other nations (Panetta, 2012). Security cooperation and building partner capacity are both political and military activities and events. These programs enable the U.S. to have access in locations of geostrategic importance, maintain comprehensive and integrated military operational capabilities all around the world, and project military power to confront universal security challenges. As the U.S. General Martin Dempsey said (2014), building partnership capacity is one way that enables the U.S. to influence the security environment around the world. The remaining U.S. concepts of choice are to use direct military action or enabling other actors.

Security assistance programs promote the U.S. defense industrial base and economy because of the American military sales and arms transfers (Blanco, 2015). Through these sales, the U.S. defense industry is "injecting additional revenues and boost[s] the health of the [U.S.] industrial base throughout the supply chain, help[s] sustain a larger industrial base to increase competition for domestic programs, make[s] domestic firms more competitive in the international marketplace, and provide[s] additional incentive to invest in innovation," (Davis, 2016). For example, the U.S. FMS system "managed \$33.6 billion in sales in 2016, and has been hitting historical highs in dollar value in recent years," (AIA, 2017). Because of its importance to U.S. security and economy, security cooperation is a major concern for the U.S. Administrations, for both the DOS and the DOD, as well as for the U.S. Congress.

Greece as a U.S. ally together with its neighboring country Turkey have had a long history as users of and participants in U.S. security cooperation programs.

\section{U.S. Security Assistance to Greece: A Historical Overview}

In 1947, under the Truman Doctrine, both Greece and Turkey received emergency U.S. aid of $\$ 400$ million each to counter Soviet pressures and overcome the challenges of the Greek Civil War (the first "hot conflict" of the Cold War) (Bozikas 1998, 15; Aseltine et al., 2016, A2-5). Since then and following the accession of Greece into NATO, the HNDF benefitted from major U.S. military grant aid programs until the 1980s, e.g., the U.S. Military Assistance Program (MAP). Nevertheless, U.S. military assistance to Greece under MAP during the 1950s and 1960s posed certain challenges both for the domestic politics and the economy of Greece as well as for its unique national security interests. However, the U.S. foreign and security policies during the Cold War treated Greece and Turkey differently. The U.S. viewed Turkey as an inherent part of the "containment policy" against the U.S.S.R. Thus, under the Truman Doctrine since the late-1940s the Turkish armed forces were lavishly supplied with U.S. military aid and equipment both in terms of quantity and quality, and with corresponding technical assistance for the successful absorption and integration of the relevant weapons systems (Athanassopoulou, 2014).

In a different way, the quantity and quality of U.S. military aid to Greece, was initially tailored for the preservation of domestic security and not for defending the country's borders in the post-Greek Civil War era (Roubatis 1987, 71). The results became rather obvious when Greek national security interests collided with those of Turkey (and the U.S.) regarding the preservation of the national independence and territorial integrity of the independent island Republic of Cyprus in 1963-1964. At that time, a Turkish military invasion of Cyprus and a Greek-Turkish military confrontation were narrowly averted because the U.S. did not want to risk a Soviet intervention and the disintegration of NATO's southeastern flank (Bozikas 1998, 17-18; Kassimeris 2008, 104). ${ }^{4}$

The continuous Greek reliance on U.S. supplied military equipment under MAP created a number of unintended consequences for Greek national security. The HNDF continued to operate rather antiquated equipment with low original purchase cost. ${ }^{5}$ As Bozikas $(1998,38)$ pointed out, only in the late-1960s and early-1970s, did Greece start to

${ }^{4}$ During the 1964-1965 periods, the Turkish Air Force (THK) possessed a numerical superiority of 1.6:1 in combat aircraft over the HAF and a 2.5:1 superiority in U.S. manufactured supersonic combat aircraft (e.g., North American F-100, Lockheed F-104G, Northrop F-5A/B). The attitude of the elected Greek government during the 1963-1964 Cyprus crisis, the continuous intervention of the U.S. in Greek politics, and domestic political instability led to the establishment of a U.S.-supported military junta in Greece in 1967-1974. During the 1967 Cyprus crisis the THK numerical superiority over the HAF had reached a ratio of 2.5:1 for the overall number of fighter aircraft and a 3:1 ratio for supersonic combat aircraft.

${ }^{5}$ For example, in the early-1970s the Hellenic Army was still using GM and Dodge vehicles, M1 Garand rifles, and Thompson submachine guns of WW II vintage. Its U.S.-supplied M-47 tanks had a range of only 70 road miles. Ogorkiewicz, R., Tanks: 100 Years of Evolution, Osprey Publishing, Oxford, UK, 2015, 164. 
diversify its arms procurement with the ordering and purchase of modern equipment from Western European countries (e.g., AMX-30 main battle tanks and Combattante missile-guided attack craft from France, and HDW U209/1100 submarines from Germany). Thus, the HNDF were obliged to sustain high maintenance costs for aged systems while relying on a supply chain that extended across the Atlantic Ocean for spare parts. The U.S. MAP items of older vintage and with a low original purchase cost also created a probable disincentive for the development of the Greek domestic defense industrial base.

The Turkish military invasion of Cyprus in July-August 1974, and the evolving Turkish threat for the Greek islands in the Eastern Aegean Sea radically reoriented Greek national security interests, policies and priorities. ${ }^{6}$ The post-1974 governments in Greece also sought a redefinition of the political and operative structure of the U.S. military assistance programs. The initiatives sought to maintain a relative balance between the military forces of Greece and Turkey (concept of credible and adequate deterrence), and to establish and improve a domestic defense industrial base for the support of the HNDF, such as the establishment of the Hellenic Aerospace Industry (HAI) with technical assistance from Lockheed Martin in the mid-1970s. The maintenance of the military balance between Greece and Turkey relied for a period of time on the ' 7 to 10 ' ratio that reflected a historical proportion of U.S. military assistance values in the aggregate that respectively flowed to the two countries (Laipson, 1985; Stearns, 1992, as both quoted in Bozikas 1998, 25). The bilateral defense and industrial/economic cooperation agreements (DECA, 1997) linked the operations of U.S. bases in Greece with the framework of military assistance and the improvement of the Greek defense industrial base.

During the 1980s and until 2009, Greece also undertook major military equipment modernization programs on its own. Through the U.S. FMS program, Greek defense procurement included the acquisition of the modern fighter aircraft Lockheed Martin F-16C/D Block 52+ for the Hellenic air Force (HAF) and associated precision guided munitions (PGMs), and Boeing Chinook CH-47DG/SD transport and AH-64A/D Apache attack helicopters for the Hellenic Army Aviation. Greece still takes advantage of the U.S. EDA program until recently (Valmas, 2014a). ${ }^{7}$ In November 2015, the Hellenic Ministry of National Defense formally funded the acquisition of an additional 10 CH-47D Chinook helicopters at a total cost of $\$ 125.8$ million with payments running from 2015 to 2022 (Valmas, 2015).

Nowadays, more than the past, the current security environment around Greece demands that both Greece and the U.S. should focus their attention on identifying areas for strengthening their strategic relationship and providing a critical deterrent to potential military conflicts in the region.

\section{Current Challenges in the Balkans, the Eastern Mediterranean, the Middle East, and North Africa}

At the present time, Greece is a stable democracy in the Balkans and the Eastern Mediterranean regions. It is a NATO member that continues to spend more than $2 \%$ of its GDP in defense, as NATO Secretary General Jens Stoltenberg said at the European Parliament in 2016 (Stoltenberg, 2016). ${ }^{8}$ Citing the U.S. Department of State (2016a), Greece has been an "ally to the U.S. in promoting Balkan stability and economic development, supporting Turkey's bid for accession to the European Union, and supporting the diversification of Europe's energy supplies." The high level of the U.S.-Greece relationship is mirrored in their mutual defense cooperation agreement which provides for the operation by the U.S. of a naval support facility at the deep-water port and airfield at Souda Bay on the Greek island of Crete. The U.S. military utilizes this base for the U.S. Navy $6^{\text {th }}$ Mediterranean Fleet and U.S. Air Force units. This is a very important military base with anchorages and the longest runways in the Eastern Mediterranean and was used for the NATO air operations in Libya in 2011. Greece also maintains good relations with Middle East and North Africa (MENA) countries, including Iran. This makes Greece an important ally for the U.S. in engagement and dialogue with the Muslim world. Beyond that, Greek national security and U.S. foreign policy interests face a series of new challenges in the Balkans and the Eastern Mediterranean, where Turkey is a key player but it is suffering from increased levels of unpredictable domestic political instability and authoritarianism (Shafak, 2017; Economist, 2016b; The Guardian,

\footnotetext{
${ }^{6}$ As Rossides (2002) recounts, Turkey has violated the U.S. Foreign Assistance Act of 1961 and the U.S. Foreign Military Sales Act by using U.S.-supplied weapons for defensive purposes to invade the sovereign Republic of Cyprus. Meanwhile, the unlawful 1974 Turkish military invasion of Cyprus and occupation of Cypriot territory have violated numerous UN Security Council Resolutions including but not limited to Nos. 353, 354, 355, 358, 360, 365, 375 (1974), 541 (1983), 774 and 789 (1992) (Coufoudakis, 2008; Rossides, 2002). In addition, the European Court of Human Rights (ECHR) has issued a number of binding decisions affirming that the unlawful Turkish military invasion and occupation have violated the basic human rights of the Cypriots (ECHR 2014;2009).

${ }^{7}$ For example, the transfer of surplus stocks of M113 armored personnel carriers or APCs.

${ }^{8}$ Greece contributes to NATO operations in Afghanistan and Kosovo, as well as to counterterrorism and counter-piracy maritime efforts in the Horn of Africa. It also participates in numerous missions abroad with NATO or European Union (EU) forces (e.g., in Mali).
} 
2016).

In the Balkans, Turkey exerts influence beyond its borders. Turkey's advantage in the Balkans, combined with ongoing regional instability, gives the impression of the establishment of a "Turkish network" in the region and creates fears of isolation in Greece and Bulgaria (Economist, 2016c; Couloumbis \& Dokos 1994, 282). Meanwhile, the region of the Balkans itself is suffering from inherent instability because of ethnic tensions and socioeconomic strains such as high unemployment levels in sensitive areas (e.g. Bosnia-Herzegovina, the Former Yugoslav Republic of Macedonia, Kosovo, etc.) (Vrbensky, 2009).

In the Middle East and the North Africa regions, Turkey has adopted a rather peculiar and risky foreign policy with active and counterproductive involvement in the Syrian crisis (Itani \& Stein 2016; Grigoriadis, 2015; Stein, 2014) while aiming to revise the 1923 Treaty of Lausanne status which applies to the Balkans, the Middle East and the North Africa regions. This unfounded demand has raised tensions amongst neighboring countries (Kitsantonis, 2017), as it openly demonstrates Turkey's aggressive and revisionist policies that are capable of creating undesirable ripple effects within the complex-adaptive system of the Middle East, North Africa, and the Balkans. Turkish aggressive policies are expected to multiply after the Kurdish referendum for independence in Northern Iraq in September 2017. An independent Kurdistan or highly autonomous Kurdish zones would signal a serious strategic setback for Turkey in its Eastern borders, and it can easily redirect Turkey's revisionist strategic goals to the West with Cyprus, Bulgaria and Greece as immediate targets (Ploumis 2016; Economist 2016c).

The discoveries of confirmed and significant undersea natural gas deposits in the Eastern Mediterranean within the exclusive economic zones (EEZs) of Cyprus, Israel, Egypt, and Lebanon, further complicate the existing geopolitical picture (Tzanetakis 2014; Kariotis, 2007). Such undersea energy deposits most probably also exist within the Syrian EEZ as well but are not present within the Turkish EEZ. For example, the undersea natural gas deposits within Cyprus' lawful EEZ have already attracted repeated Turkish threats and hostile demonstrations of military power that are part and parcel of Turkey's gradual coercive diplomacy in the region (Ploumis 2016, 34). That said, Turkey continuous and unabated challenges to Greek and Cypriot sovereignty and territorial integrity (HNDGS, 2018; To Vima, 2016).

Turkey's risky independent policy has set it at odds with the American public regarding the U.S. foreign policy and national security interests in the region (Ozkan, 2016; Weaver, 2016). For example, Turkey seems to have facilitated Iran to evade the U.S. sanctions imposed to this country because of its nuclear development program (Cupolo, 2017). Furthermore, Turkey and Qatar have played a destabilizing role in Libya through their support to extremist Islamist factions based in Tripoli, while Egypt and the United Arab Emirates had supported a more moderate faction in Tobruk. This adversarial gaming derailed UN attempts to unify fragmented administrations and their armed followers into a single Libyan governing entity (Trofimov, 2016). Most recently, in January 2018, the Hellenic Coast Guard seized a Libya-bound merchant vessel that departed from Turkey with a large load of explosives (Anadolu Agency, 2018). This interception received positive commentary in the U.S. press that also disclosed the increased Hellenic Coast Guard collaboration and intelligence sharing with U.S. government agencies in the Eastern Mediterranean (Noack, 2018). Moreover, Turkey has been actively involved in the Qatar crisis while aspiring to play a mediating role to both sides (e.g. Qatar and the rest of the Arab countries) (Aliriza, 2017). The latest Turkish military attack on locations that are held by forces of Syrian Kurds that successfully defeated with U.S. military assistance the ISIS presence in Syria speaks volumes on the Turkish lack of cooperation with the U.S. in very sensitive areas of the Middle East (BBC, 2018). Based on the above facts, various international media commenters ask that western countries should examine the role that Turkey is often playing as a global Grand Central station for terrorists (The Wall Street Journal, 2017).

When comparing Turkey to Greece, Turkey has a military power advantage (IISS, 2017) that will be increasing in the near future. The Turkish government is presently implementing a major modernization program for its armed forces (IHS Jane's, 2015), and more recently approved $\$ 5.9$ billion worth acquisition program of new defense projects (Bekdil, 2016). ${ }^{9}$ In 2017, Turkey announced that it had signed a deal with Russia to purchase the S-400 surface-to-air missile system, in a clearest sign that this country is entering Russia's sphere of influence (Gall \& Higgins, 2017), and despite NATO's misgivings about this purchase that will be partially financed through a Russian loan. This deal points out

\footnotetext{
${ }^{9}$ Turkey's ongoing modernization plan involves major programs such as the participation in the Lockheed Martin F-35 Lightning II Joint Strike Fighter (JSF) program with the requirement for at least 100 aircraft, a program to procure at least 109 multirole utility helicopters, a requirement to acquire 14 heavy lift helicopters, the procurement of up to six new Type 214 submarines, the procurement of 337 tactical wheeled armored vehicles, the procurement of the indigenously developed Anka medium-altitude long-endurance (MALE) unmanned aerial vehicle (UAV), the Firtina program, Altay project to develop and produce an indigenous main battle tank (MBT), procurement of 37 tactical reconnaissance vehicles, procurement of new landing craft tank vessels, procurement of 16 corvettes under the MILGEM program, program to procure a landing platform dock vessel. For more, see, IHS Jane's, (2015).
} 
Turkey's rapprochement with Russia as its ties with the U.S. and the EU have become strained.

Table 1. Defense Expenditure: Greece Compared to Turkey (2009-2017)

\begin{tabular}{|c|c|c|c|c|c|c|c|c|c|}
\hline & 2009 & 2010 & 2011 & 2012 & 2013 & 2014 & 2015 & 2016 & 2017 \\
\hline \multicolumn{10}{|c|}{ Real GDP (billion US dollars). 2010 prices and exchange rates } \\
\hline Greece & 317 & 299 & 272 & 252 & 244 & 245 & 244 & 244 & 247 \\
\hline Turkey & 670 & 772 & 855 & 895 & 975 & 1,024 & 1,084 & 1,117 & 1,156 \\
\hline \multicolumn{10}{|c|}{ Defense Expenditures (million US dollars). 2010 prices and exchange rates } \\
\hline Greece & 9,748 & 7,902 & 6,482 & 5,782 & 5,401 & 5,420 & 5,664 & 5,821 & 5,720 \\
\hline Turkey & 13,785 & 14,134 & 13,982 & 14,237 & 14,803 & 14,886 & 15,080 & 16,449 & 17,546 \\
\hline \multicolumn{10}{|c|}{ Defense Expenditure as Share of Real GDP $(\%)$ based on 2010 prices } \\
\hline Greece & 3.08 & 2.64 & 2.38 & 2.29 & 2.21 & 2.21 & 2.32 & 2.38 & 2.32 \\
\hline Turkey & 2.06 & 1.83 & 1.64 & 1.59 & 1.52 & 1.45 & 1.39 & 1.47 & 1.52 \\
\hline \multicolumn{10}{|c|}{ Distribution of total defense expenditure in Equipment (\%) } \\
\hline Greece & 27.75 & 17.98 & 5.86 & 7.47 & 12.06 & 8.17 & 10.26 & 13.43 & 15.44 \\
\hline Turkey & 25.61 & 27.98 & 24.57 & 21.21 & 26.89 & 25.08 & 25.13 & 25.59 & 30.40 \\
\hline \multicolumn{10}{|c|}{ Distribution of total defense expenditure in Personnel (\%) } \\
\hline Greece & 56.52 & 65.07 & 76.03 & 73.19 & 74.56 & 77.18 & 72.05 & 73.13 & 72.19 \\
\hline Turkey & 49.61 & 49.75 & 53.02 & 56.02 & 54.58 & 56.88 & 56.82 & 57.69 & 53.28 \\
\hline \multicolumn{10}{|c|}{ Military Personnel (thousands) } \\
\hline Greece & 135 & 128 & 117 & 110 & 110 & 107 & 103 & 106 & 107 \\
\hline Turkey & 495 & 495 & 495 & 495 & 427 & 427 & 399 & 373 & 387 \\
\hline
\end{tabular}

Source: NATO $(2017 ; 2016)$. Figures for 2017 are estimates. The author created the table using information from the source.

Greece and Turkey are allies in NATO and both maintain relations with the U.S. In case of Turkish aggression against Greek sovereignty, NATO will not guarantee its containment in advance. The North Atlantic Treaty does not secure an automatic response by the allies in the event of an attack, "the allies are only pledged to consult as a group by Article 5 prior to determining the necessary response," (Sandler \& Hartley, 1999). This time lapse from hostile action to an allied response is the same challenge that the Baltic countries face as NATO members with their concerns growing over a resurgent Russia at their borders (Shlapak \& Johnson, 2016). Furthermore, as the unlawful Turkish military invasion of Cyprus in 1974, and the Greek-Turkish Aegean Sea crises have demonstrated, NATO is both unwilling and ill-equipped to timely handle a potential armed conflict among its own members.

The same response is expected from the EU, of which Greece and Cyprus are members, because the established EU Common Foreign and Security Policy (EU CFSP) necessitates consensus among all sovereign countries to make decisions upon such issues (Mix, 2013). Meanwhile, the road towards an integrated EU security approach which was announced recently with the establishment of the Permanent Structured Cooperation on Security and Defence (PESCO), following the "European Action Defense Plan," seems to be rough and long (EC 2017).

For Greece to counter Turkey, conventional deterrence has been and continues to be the first line of defense as it is usually true that, a mutual respect exists between equals and "as the world goes, [right] is only in question between equals in power, while the strong do what they can and the weak suffer what they must," as Thucydides postulates (Strassler 1996, 352). As Buchan (1968, 7; also quoted in Blainey 2013, 122) pointed out, the lack of a military balance between countries increases fears for armed conflicts because such a lack "creates a clear temptation to aggression," that can easily escalate to a war. The historical experience of Greek-Turkish relations (Couloumbis \& Dokos, 1994; Nation 2003) combined with Turkey's regional military power and its actions create fear of war among the Greeks. In the absence of a relevant military balance, a limited or more conventional military confrontation between Greek and Turkish military forces is a distinct possibility as it happened in the past (e.g., Cyprus 1974, Aegean Sea crises of 1976, 1987, and 1996 at the Imia islet). ${ }^{10}$ However, for Greece other measures including bilateral and multilateral security arrangements remain an open alternative to counter Turkey (Markezinis 2011, 389-391).

The maintenance of a relative military balance between Greece and Turkey is a stabilizing factor in the region, and both U.S. and NATO should have a concrete interest in maintaining it. Greece was and it continues to be a buffer zone between East and West as Greeks have a long history of defending the West (Baroudos, 2015). Currently, Greece is gradually becoming an energy gateway for natural gas that is flowing into Europe from Central Asia and Turkey. Potentially, Greece can also become the preferred pipeline route to Western Europe for undersea natural gas deposits that have been confirmed in the Eastern Mediterranean (e.g., EEZs of Cyprus and Egypt), as well as for undersea hydrocarbon resources that are believed to exist within the Greek EEZ as well (Mathiopoulos , 2017). Such an outcome can increase the energy

${ }^{10}$ See also, Grigoriadis, I. N. (2012). 
security of Western European countries by lessening their dependence on imported Russian energy supplies. Although the U.S. is an energy dominant nation (NSS 2017), the destabilization of the Eastern Mediterranean and Middle East regions would dramatically affect the global economy and have long-term consequences in the U.S. economy as well. The U.S. also needs to appropriately react to developments and realignments in the broader Middle East and North Africa (MENA) region (e.g., Syria Crisis, ISIS, Al Qaeda, etc.).

Meanwhile, the future of Euro-U.S. security cooperation remains ambivalent. This situation raises questions for the concrete operation of the EU Common Security and Defence Policy (EU CSDP) (Howorth 2013). At present, and in the near future, Greece cannot undertake major modernization programs for the HNDF because of its financial constraints and the close supervision of its international lenders. In the meantime, the large refugee flows from the Middle East war zones have imposed tremendous stress on the financially constrained Greek domestic security forces that are supported by the HNDF to deal with the crisis (Ploumis, 2016).

In this context, common Greek and U.S. security interests in the Balkans and the Eastern Mediterranean, in view of the instability in these regions and the inherent unpredictability of the Turkish foreign policy, necessitate enhanced U.S. security assistance programs for the HNDF to enable their modernization following a rebalanced concept, which demands a mutual effort to "help others help themselves," in a win-win geostrategic game.

\section{A Framework for the Future}

The preceding analysis briefly demonstrated that Greece has benefited by the U.S. security cooperation programs since WW II, while the security challenges for both Greece and the U.S. have recently increased because of the instability in the region and the Turkish revisionist policies that are combined with Turkey's preponderance of military power in the region. The U.S. also has concrete interests in the region and its security assistance efforts need to be solidly embedded in its foreign policy (Adams \& Williams, 2011).

In the near future, the HNDF will confront modernization issues because of Greece's financial constraints. Collins (1994) (as quoted in Galvin, 2014, 3) pointed out that "armed forces perform best when manpower, weapons, equipment, and supplies are superior to those of the most capable prospective opponents" Thus, qualitative superiority of the armed forces of a nation-state is a requirement to deter enemies, and fight and win a nation's wars in the modern era of advanced military technology. Taking into consideration Greece's security challenges, the HNDF modernization programs are of major importance for maintaining the balance of military power in the Eastern Mediterranean. In the context of the economic crisis and the availability of limited financial resources, the HNDF priorities regarding modernization programs are presumed to be the following:

The assured supply of spare parts and subassemblies for the maintenance of existing weapons systems and platforms is the first priority. Second, the upgrades of existing major weapons systems and platforms. Third, there is the need for the procurement of sufficiently modern weapons systems so that the HNDF can maintain sufficient and credible deterrent capabilities in the Eastern Mediterranean region. Fourth, there is a requirement for the continuous development of the domestic defense industrial base for the HNDF to continue to have an indigenous source of essential military supplies and materiel (e.g., military consumables such as ammunition, as well as petroleum, oil and lubricants).

To meet future security challenges, especially in the field on HNDF modernization, Greece should seek to rebalance its security cooperation with the United States. Top military commanders from both countries have expressed the need to strengthen bilateral cooperation to meet security challenges in the region (e-kathimerini, 2017). Following this concept, the United States, has expanded its joint collaboration and intelligence sharing in Greece with the Hellenic Coast Guard (Noack, 2018), while top American diplomats in Athens broach the issue of the establishment of a new mutual defense cooperation agreement with Greece for the uses of the "Best in the Med," base of the Souda Bay (Nedos 2017). Similarly, joint military exercises involving all branches of the HNDF and the U.S. Armed Forces as well as other nations (e.g., Israel), are routinely carried out within Greek sovereign territory.

In this context, this paper will further identify some relevant U.S. security cooperation programs that can be supportive to the HNDF after appropriate realignment to address the national security requirements and concerns of both allies.

First, the FMFP can support the HNDF acquisition programs for sufficiently modern weapons systems or upgrades of existing systems and platforms. Greece is not and has not been within the recent past a recipient of U.S. FMFP financing. Naturally, Greece does not expect to receive the annual levels of U.S. free military aid that is provided to countries such as Israel (currently \$3-\$3.2 bn. annually) and Egypt. However, Greece could negotiate with the U.S. appropriate FMFP arrangements under two premises. The first premise involves Greek government negotiations with the U.S. of a new defense cooperation agreement about the continuous operation of the United States air-naval support facility at Souda Bay in Crete. In 1999, Greece entered into the initial 8-year long agreement with the U.S. for the Souda base in exchange for a U.S. military assistance program valued more than $\$ 1$ billion (Anastasi, 1990). Since then, no major amendment or renegotiation of this agreement has been publicly announced. The economic crisis in Greece 
and the corresponding decreases in military spending strongly suggest that the re-negotiation of the terms of this particular agreement is one way that is possible for Greece to receive adequate U.S. military assistance through the FMFP (noting that the FMFP is also dependent on budget constraints that are legislated by consecutive U.S. Administrations and the U.S. Congress).

The second premise is that the Greek government can negotiate with the U.S. for Congressionally appropriated long-term and low interest rate loans. These loans would enable Greece to purchase U.S. defense articles through either the FMS or the DCS programs and gradually pay them off over a period of 12 years or more rather than paying up front a substantial part of the original purchase cost. ${ }^{11}$ Greece has experience in FMS programs. Between 2006 and 2013, as Perris $(2015,18)$ pointed out, Greece made significant FMS purchases. In 2006 through FMS, Greece purchased 30 F-16s Block 52+, a sale worth of \$2 billion, while recently (October 2017) a possible FMS project for the Government of Greece has been announced involving an upgrade of HAF F-16 fighter aircraft of various vintages to the F-16 Block V configuration with an initially estimated cost reaching \$2.404 billion (DSCA, 2017).

Both the FMFP and FMS programs can be leveraged so that, for example, when the USAF and/or the U.S. Navy will respectively replace Lockheed Martin F-16 Fighting Falcon and Boeing F-18 Hornet combat aircraft with the F-35 Joint Strike Fighter, the withdrawn aircraft can be appropriately transferred to the HAF with the HAI undertaking appropriate modifications as needed.

Second, EDA programs through which Greece can obtain weapons systems and defense articles that are no longer in use in the U.S. military or are surplus equipment. Greece routinely takes advantage of this particular program and has already incorporated in its Army many EDA articles. Between 2000 and 2014 as Perris (2015, E1) valuable research indicated, Greece obtained EDA articles worth of \$78 million, in their current state-including repair charges and transportation costs, while their original acquisition value for the U.S. government was $\$ 642$ million. More recently, in December 2017, it was announced that the Hellenic Army will receive 70 OH-58 D Kiowa Warrior armed reconnaissance helicopters that have been withdrawn from service with the U.S. Army Aviation, for a cost of 46 million Euros (Dailyhellascom 2017).

The problem with these transfers is the requirement for the recipient to pay five to fifty percent of the original acquisition value as well as any repair charges and transportation costs from the place where such articles are located to the recipient country (Aseltine et al. 2016, 1-7). In 2014, despite the U.S. approval for Greece to receive 460 M113 APCs identified by DOD as EDA, the Greek government delayed their transportation because of its financial constraints (Valmas, 2014a). Finally, Greece managed to finance the necessary transportation and these APCs were incorporated in the Hellenic Army inventory. As Aseltine et al. (2016, 1-7) recounts "while EDA can be transferred at no-cost, the recipient must typically pay for any transportation or repair charges. Under certain circumstances, the transportation charges can be waived, with the cost absorbed by [the U.S.] DOD.” Thus, for Greece to take full advantage of such programs, it should negotiate EDA transfers with the DOD at no-cost, while related repair and/or transportation charges can be waived and absorbed by the U.S. DOD for a certain time period, because of the particular circumstances of the Greek economy.

Such U.S. Security Assistance programs as recounted above and are related with arms acquisition by Greece should support in parallel the Hellenic Defense Industrial Base (HDIB) under the existing or amended defense industrial/economic cooperation agreements. ${ }^{12}$ These agreements should take into consideration the HDIB in a similar way as the U.S. deals with the Israeli defense industrial base. As Reuters (2016) reported, in the recent past from the annual free $\$ 3$ billion U.S. military assistance to Israel a $26.3 \%$ of the aid amount would flow directly to the Israeli defense industry. Despite the very respectable annual United States free military assistance to Israel, as SIPRI (2015) and Metz (1990) recounted, Israel itself ranks high as an exporter of sophisticated weapons systems to other countries often in competition with U.S.-based defense industries. In the same way, Turkish defense equipment manufacturers have also benefited from the inflows of military technology and "know-how" from the U.S. ${ }^{13}$

The HDIB mainly produces products of modest technological content that do not secure HNDF supply lines and sustainment (Ploumis 2017; Kollias \& Rafailidis, 2003; Dunne, Nikolaidou, \& Mylonidis, 2003; Curtis, 1994). However, it includes shipyards with dual civilian and military roles as well as some very innovative enterprises that make a significant amount of exports in cutting-edge defense equipment components. Meanwhile, new technologies have

\footnotetext{
${ }^{11}$ FMFP consisted of non-grant loans are usually repayable in 12-year timeframe.

${ }^{12}$ For example, the DECA (1997).

${ }^{13}$ The most well-known programs are the co-production of F-16 fighter aircraft (Turkish Aerospace Industries or TAI and the U.S. Lockheed Martin), and Turkey's partnership involvement in the Lockheed Martin F-35 Joint Strike Fighter program.
} 
emerged in the U.S. defense industry such as computer assisted 3-D metal printing and additive manufacturing in the aerospace industry, e.g., production of jet engine fuel nozzles and compressor blades (Michaels, 2016). The HDIB should take advantage with appropriate technology transfers in collaboration with the U.S. defense industry under enhanced U.S. security assistance programs in Greece.

The Greek defense industry took advantage of the FMS programs in the past as well as from the Greek government initiatives for collaborative defense production projects in Greece. For example, the HAI was co-producer with Lockheed Martin of rear fuselages for F-16 fighter aircraft thanks to the offsets programs that the Greek government implemented when Greece purchased the F-16s. Similarly, procurement of new military equipment or modernization of existing weapons systems should involve co-production and military technology transfer arrangements with the U.S. defense firms. ${ }^{14}$ Such co-production programs would keep domestic industrial production lines open and enable the HDIB to remain in the market for the benefit of HNDF's sustainment (Dokos \& Kollias 2013). This kind of arrangements and support to HDIB do not contradict the European legislation on defense contracting (e.g. Directive 2009/81/EC) which Greece, as an EU member fully implements, because defense contracts that are "awarded by a government to another government," under certain circumstances can be excluded from the European Commission's (EC) jurisdictional oversight (EP \& C 2009). The Greek government follows this path and recently engaged the HDIB (i.e., HAI) with the upgrade of five P-3 Orion maritime surveillance and anti-submarine warfare aircraft that exist in the Hellenic Navy and HAF inventory.

Third, Greece should seek U.S. aid through the ESF, U.S. Agency for International Development (USAID - part of the U.S. DOS) to cover part of the expenses that Greece has expended and continues to spend for supporting the refugees coming from the Middle East war zones. Greece has been supported by the EU in these efforts albeit partially and with great delays. However, it is the author's view that the country should also ask for support from the U.S. The U.S. economic support fund is made available usually on a grant basis to countries to protect current political and security interests. To deal with the refugee crisis, Greece engaged and continues to engage both its domestic security forces (e.g., Hellenic Coast Guard, Hellenic Police), and the HNDF (e.g., Army construction and management for refugee encampments), and it spends funding coming also from the defense budget. For example, only for the Lesbos Island's refugee encampments, Greece spends approximately $€ 1.5$ million/per month to feed 7.300 refugees and migrants that are stranded on this island (diavgeia, 2017). The instability in the MENA region and the long-term effects of armed conflicts and U.S. military interventions have unintended consequences for geopolitical and demographic parameters that currently affect Europe and Greece in particular (e.g., the largest refugee and immigrant flows since the end of WW II) (Ploumis \& Pilalis, 2016). ${ }^{15}$ Meanwhile, migration flows that are impacted by environmental factors will rise in the near future (Knomad, 2017), a situation that would have dire consequences to Greece, as the country is the front gate for migrants that attempt to enter the EU from the Middle East, Africa, and Asia (e.g., Afghanistan).

Under the U.S. security assistance policy (PPD 23, 2013), the U.S. helps its allies and partners build sustainable capacity to address common security challenges such as to disrupt and defeat transnational threats. The USAID is the organization that mainly executes this policy. In March 2016, the U.S. Department of State (2016b) announced the allocation of $\$ 20$ million to support the efforts by the Office of the United Nations High Commissioner for Refugees (UNHCR), the United Nations Population Fund (UNFPA), and the International Federation of Red Cross/Red Crescent (IFRC) to respond to increased needs for protection, shelter, and other humanitarian assistance throughout Europe, including Greece, Western Turkey, and the Balkans. For the Fiscal Year (FY) 2018, the U.S. has announced that it will allocate \$46.4 million for assistance programs in Europe to assist amongst others vulnerable migrants stranded in Greece (FY 2018, 2017, p. 309). Based on these facts, Greece should seek direct grant assistance from the United States to deal with the refugee crisis amidst the persistent fiscal constraints that face the Greek government budgets, since Greek territory is the primary entry point into the European Union Schengen Convention visa area for migrants from the Middle East, North and Sub-Saharan Africa, and Southwest Asia.

Finally, DOD administered security cooperation programs involving IMET assistance and military engagements should be increased to foster cooperation, and build relations and trust between the HNDF and the U.S. military. IMET grant financial assistance for training in the U.S. extended to Greek military and related civilian personnel is below $\$ 200,000$

\footnotetext{
${ }^{14}$ “'Technology transfer is the process of transferring, from an industry in one country to another or between governments themselves, technical information and know-how relating to the design, engineering, manufacture, production, and use of goods." For more on this matter in combination with the U.S. security assistance policy, see Aseltine, et al. Chapter 7.

15 For statistical data on illegal immigration (in Greek), see Hellenic Police archives at: http://www.astynomia.gr/index.php?option=ozo_content\&lang=\%27..\%27\&perform=view\&id=70776\&Itemid=1240\&1 ang $=[$ Accessed January 14, 2018].
} 
and less per year in the last decade (U.S DOS, 2016c) which is an extremely low figure. Unfortunately, the US DOS, for the FY 2018, has allocated to Greece only $\$ 150.000$ for IMET, a reality that will negatively affect military cooperation between the two countries in the near term (FY 2018, p. 378). Greece finances and sends a large number of military personnel to U.S. educational institutions. However, Greek domestic financing for military training in the U.S. is likely to decrease in the near future because of reduced defense budgets. Under these circumstances, the U.S. IMET grant financial assistance should increase to keep Greek military training in the U.S. at the same level as it is today for both countries' mutual benefit.

Combined exercises between the U.S. Forces and HNDF in Greek territory could also be expanded. The U.S. Armed Forces and the HNDF periodically plan and execute various combined arms exercises together and with the participation of military forces from other countries including non-NATO members such as Israel. ${ }^{16}$ The military cooperation between the HNDF and the U.S. military is at a very good level and the HNDF can always take advantage of new tactics and procedures that the U.S. forces bring with them. Such military-to-military engagements will support the sustainable establishment of professional relationships between Greece and the U.S. military.

U.S. military contacts programs such as SPP should also be taken into consideration for HNDF to participate. Because U.S. National Guard units have a dual military and civilian support role (e.g., a state governor can mobilize National Guard units in case of a natural disaster or civil unrest), they are capable of interacting with both the military and civilian authorities of other countries in the context of SPP partnering activities. Greece, because of its unique national security interests must take into careful consideration whether: (1) It should participate in SPP activities with U.S. National Guard units; and, (2) what would be the parameters of such potential participation. For example, such participation could be utilized with military assistance programs (e.g., U.S. Air National Guard F-4E fighter aircraft were transferred directly to the Hellenic Air Force after the 1990-1991 Gulf War), or for better access to the U.S. national security decision making centers (e.g., SPP collaboration with the U.S. National Guard units of the District of Columbia, in the Washington, D.C. area).

The U.S. security cooperation programs as described above would support the HNDF during a critical period for the Greek economy and maintain the necessary level of stability in the Balkans and the Eastern Mediterranean that is a particular concern for the U.S. national security. The HNDF are active participants in policing the sensitive region of the Eastern Mediterranean. For example, HAF AWACS aircraft participated in the NATO air operations over Libya in 2011, and Hellenic Navy missile guided frigates conducted humanitarian evacuations both from Libya in the same year and from Lebanon in the aftermath of the Second Lebanon War in 2006. In 2014, under the NATO concept of smart defense, Greece signed with Bulgaria a technical agreement that the Hellenic Air Force (HAF) could begin policing Bulgarian airspace (Valmas, 2014b). Similarly, HNDF bases and other infrastructure such as the bases on Crete facilitate various U.S., NATO and EU stability operations in the MENA region.

\section{The Process}

For Greece to succeed in achieving grants, long terms loans and low interest rates for arms acquisition programs as well as improved security cooperation as described above is a matter of negotiation with a multi-level approach and with appropriate political decisions. Aseltine et al. (2016, 3-1 to 4-44) explain the systematic series of actions through the U.S. government organizations for security assistance. Such process involves U.S. roles and the formulation of a comprehensive and integrated "interagency" policy that includes a team ranging from the U.S. Ambassador and the relevant U.S. Country Team in Athens, to the Commander of the U.S. European Command, the DOS and DOD, the White House, and the U.S. Congress. Weed et al. (2014), Jones (2014) and Neumann (2015) did useful work on analyzing how this U.S. interagency policy process works. A similarly coordinated Greek government team (e.g., participation by the Hellenic Ministries of Defense and Foreign Affairs), should inform their U.S. counterparts in Greece (i.e. Chief in Mission/U.S. Ambassador, U.S. Country team) and discuss how the U.S. could support HNDF sustainment in the near future. In parallel, the Greek political and military representatives in NATO should inform SACEUR who is also Commander of the U.S. European Command about the situation in Greece and seek his conveyance of properly structured proposals to the United States Administration about the Greek positions and needs. In another venue, the Hellenic Embassy in Washington D.C. should address this matter at a higher level directly with the U.S. DOS and the U.S. DOD while the Greek government itself should address the matter in the level of the White House. At the U.S. Congress level, the Greek lobby in Washington D.C. should take appropriate action as well borrowing the example from and paralleling the actions of the very active and persuasive Israeli-American organizations.

The reexamination of the U.S. military assistance programs for Greece should provide the foundation for similar defense cooperation arrangements with other countries. After WW II, Germany transferred U.S.-made M48 tanks to

\footnotetext{
${ }^{16}$ For example the recent Iniochos-Charioteer 2016 exercise involved HAF, USAF, and IDF-Aerospace Force units in Greece (Valmas, 2013; Jerusalem Post, 2015; JP Updates, 2015).
} 
Israel as part of its moral obligation because of the Jewish Holocaust during WW II. Most recently, Germany has substantially financed the construction of the modern Dolphin class submarines that are part of the IDF-Navy and have a concrete role in the Israeli nuclear deterrence capabilities (NTI, 2015; Economist, 2016a). Greece can negotiate a similar arrangement for military aid grants from Germany as part of the unsettled Greek reparation claims following the destruction that was caused by the German forces during the WW II Axis occupation of Greece. ${ }^{17}$

\section{Concluding Remarks}

Greece currently suffers from severe economic and fiscal difficulties to fund modern weapons systems acquisitions. This will have negative consequences for the HNDF capabilities and for the overall military balance of power in the Balkans and the Eastern Mediterranean regions. Therefore, Greece should negotiate a new framework for the U.S. security cooperation. A new rebalanced framework of security cooperation would serve common national security interests of both Greece and the United States. The continuous operations of the U.S. Souda base on the Greek island of Crete can provide the necessary venue for enhanced U.S. security assistance. Such assistance should be based on the premise of U.S. grants or long-term, low interest rate loans to Greece for financing HNDF modernization and HDIB support. Preserving the HNDF capabilities also preserves needed stability in the Balkans and the Eastern Mediterranean, an overarching goal that is fully consistent with the U.S. national security interests in this sensitive region. In the same way, the U.S. security assistance should increase financial resources for the training of Greek military personnel in the U.S. and for military contact engagements, as well as enabling Greece to successfully cope with the current refugee crisis.

\section{Acknowledgments}

I want to thank Dr. Dimitrios D. Thomakos, Professor of Applied Econometrics, \& Chairman Department of Economics, School of Economics, Management \& Informatics, University of Peloponnese, and Professor Michael A. Marra, Department of Military Strategy, Planning, and Operations USAWC, for their kind review. I also extend my thanks to Mr. Labros E. Pilalis, MPA, JD, for his valuable assistance.

\section{References}

Adams, G., \& Williams. (2011, March). A New Way Forward: Rebalancing Security Assistance Programs and Authorities. Washington, DC: The Henry L. Stimson Center. Retrieved from https://www.stimson.org/content/new-way-forward-rebalancing-security-assistance-programs-and-authorities [Accessed January 14, 2018].

AIA (Aerospace Industries Association). (2017). 2017 AIA strategic priorities: Achieve security cooperation reform. Retrieved from

http://www.aia-aerospace.org/wp-content/uploads/2017/03/International-2017-Security-Cooperation.pdf [Accessed January 3, 2018].

Aliriza, B. (2017, June 28). The Qatar Crisis and Turkey: Trump and Erdogan Diverge. Center for Strategic \& International Studies (CSIS).

Retrieved from https://www.csis.org/analysis/qatar-crisis-and-turkey-trump-and-erdogan-diverge [Accessed August 14, 2017].

Anadolu Agency. (2018, January 13). Turkey launches investigation of Libyan-bound ship seized by Greece. Hurriyet Daily News. Retrieved from http://www.hurriyetdailynews.com/turkey-launches-investigation-of-libyan-bound-ship-seized-by-greece-125667 [Accessed January 13, 2018].

Anastasi, P. (1990, July 8). Greece and U.S. Sign 8-year Pact Exchanging Arms Aid for Extended Use of Bases. The New York Times. Retrieved from http://www.nytimes.com/1990/07/09/world/greece-and-us-sign-8-year-pact-exchanging-arms-aid-for-extended-use -of-bases.html [Accessed May 7, 2016].

Aseltine, W. C., Chess, B. D., Hawkins, J. B., Hawkins, P. K., Horvath, M. A., Krolikowski, C. M., O'Connor, J. B.et al. (2016, March). The Management of Security Cooperation, Eds. Grafton, J. S., Wright-Patterson AFB, Ohio: Defense Institute of Security Assistance Management. Retrieved from http://www.disam.dsca.mil/_pages/resources/default.aspx?section=publications\&type=greenbook [Accessed May

\footnotetext{
${ }^{17}$ No less than 500,000 Greeks perished during the Axis occupation of Greece in a population of approximately seven million. The Greek war reparation claims include the repayment of a loan that was forcibly extracted by the German occupation forces during WW II. The Greek reparation claims have not been "cancelled out" through various treaties that recognized the existence of post-WW II West Germany, restructured the West German economy (i.e., 1952 forgiveness of German foreign debt), and permitted the German reunification after the Cold War.
} 
29, 2016].

Athanassopoulou, E. (2014). Strategic Relations between the US and Turkey 1979-2000: Sleeping with a Tiger. New York: Routledge, 5-52.

Baroudos. (2015, October 12). Greece has a long history of defending the West. Lexington Institute. Retrieved from http://www.lexingtoninstitute.org/greece-has-a-long-history-of-defending-the-west/ [Accessed January, 13].

BBC. (2018, January 22). Syria offensive: Turkish troops 'capture villages' in Afrin. Retrieved from http://www.bbc.com/news/world-middle-east-42771469 [Accessed January 22, 2018].

Bekdil, B. E. (2016. March 9). Turkey Panel OKs $\$ 5.9$ billion in Defense Programs. Defense News. Retrieved from: http://www.defensenews.com/story/defense/policy-budget/budget/2016/03/09/turkeys-government-approves-progr ams-worth-billions/81567424/ [Accessed May 25, 2016).

Blainey, G. (2013). Power, Culprits and Arms, in Conflict after the Cold War: Argumentson Causes of War and Peace, Betts, R.K. (Eds) ( $2^{\text {nd }}$ ed). Boston: Pearson. p. 122.

Blanco, A. R. H. (2015, March 11). Military Aid - 'If We Don't Do It, Someone Else Will.' The Beacon. Retrieved from: http://blog.independent.org/2015/03/11/military-aid-if-we-dont-do-it-someone-else-will/ [Accessed March 1, 2016).

Bowling, B. (2011). Policing the Caribbean: Transnational security cooperation in practice. New York: Oxford University Press.

Bozikas, G. P. (1998, April). U.S. Security Assistance and Regional Balance of Power: Greece and Turkey, a Case Study. Strategy Research Project, Carlisle Barracks, PA: U.S. Army War College. Retrieved from http://usahec.polarislibrary.com/polaris/search/searchresults.aspx?ctx=1.1033.0.0.1\&type=Keyword\&term=14685 $5 \& b y=C N \&$ sort=RELEVANCE\&limit=TOM=*\&query=\&page=0\&searchid=1 [Accessed May 29, 2016].

Buchan, A. (1968). War in Modern Society: An Introduction. London: Harper Colophon Books, p. 7.

Collins, J. M. (1994, January 21). Military Preparedness: Principles Compared with U.S. Practices. Report no. 94-48S, Washington, DC: Congressional Research Service, 41-49.

Coufoudakis, V. (2008).International Aggression and Violations of Human Rights: The Case of Turkey in Cyprus. Minneapolis: University of Minnesota), 1-2 \& n. 4.

Couloumbis, T., \& Dokos, T. (1994). Assessing the Turkish Threat, in Greece: a Country Study, Eds Curtis, G.E (4 ${ }^{\text {th }}$ ed.). Washington, DC: Federal Research Division, Library of Congress, 279-282.

Cupolo, D. (2017, November 29). The unyielding paranoia of Recep Tayyip Erdogan. The Atlantic. Retrieved from https://www.theatlantic.com/international/archive/2017/11/zarrab-erdogan-turkey-iran-sanctions/546986/ [Accessed January 4, 2018].

Curtis, G. E. (Eds) (1994). Greece: a Country Study, (4 $4^{\text {th }}$ ed.). Washington, DC: Federal Research Division, Library of Congress.

Dailyhellas.com. (2017, December 21). Hellenic Army to receive 70 OH-58 D Kiowa Warrior armed reconnaissance helicopters from US Army. Retrieved from: https://dailyhellas.com/2017/12/21/hellenic-army-to-receive-70-oh-58d-kiowa-warrior-armed-reconnaissance-helic opters-from-the-us-army/ [Accessed December 27, 2017].

Davis, T. M. (2016). U.S. Industry Perspectives on the Department of Defense's Policies, Roles, and Responsibilities for Foreign Military Sales Testimony before the Committee on Armed Services United States House of Representatives Subcommittee on Oversight and Investigations. Retrieved from http://docs.house.gov/meetings/AS/AS06/20160511/104900/HHRG-114-AS06-Bio-DavisT-20160511.pdf [Accessed January 11, 2018].

DECA. (1997, April 4). Defense Industrial Cooperation Agreement between the Government of the United States of America and the Government of the Hellenic Republic. Retrieved from http://www.acq.osd.mil/dpap/Docs/mou-greece.pdf [Accessed May 8, 2016].

Dempsey, M. (2014, May 12). Dempsey Wants to Rebalance the use of Military Power. Defense One. Retrieved from:http://www.defenseone.com/ideas/2014/05/dempsey-wants-rebalance-away-use-military-force/84271/ [Accessed May 25, 2016].

Diavgeia. (2017). Retrieved from https://diavgeia.gov.gr/doc/6\%CE\%9F\%CE\%9776-\%CE\%958\%CE\%A1?inline=true [Accessed January 14, 2018]. 
Dokos, T., \& Kollias, C. (2013, March). Greek Defence Spending in Times of Crisis: The Urgent Need for Defence Reform. ELIAMEP Thesis. Retrieved from: http://www.eliamep.gr/wp-content/uploads/2013/03/ELIAMEP-Thesis-1-2013_Th.Dokos-Ch.Kollias1.pdf [Accessed March 28, 2016].

DSCA (Defense Security Cooperation Agency). (2017, October 17). Government of Greece - Upgrade of F-16 Aircraft to F-16 Block V Configuration. from: http://www.dsca.mil/major-arms-sales/government-greece-upgrade-f-16-aircraft-f-16-block-v-configuration [Accessed December 27, 2017].

Dunne, J. P., Nikolaidou, E., \& Mylonidis, N. (2003). The Demand for Military Spending in the Peripheral Economies of Europe. Defense and Peace Economics, 14(6), 447-460. https://doi.org/10.1080/1024269032000085215

EC (European Commission). (2017). European Defence Action Plan, (Brussels, 30 November 2016), COM(2016) 950 final; European Commission, Press Releases, The European Defence Action Plan - Frequently Asked Questions, http://europa.eu/rapid/press-release_MEMO-16-4101_en.htm, [Accessed December 1, 2016; EU, Permanent Structured Cooperation (PESCO), (Brussels, 13 November http://www.consilium.europa.eu/media/31511/171113-pesco-notification.pdf, [Accessed November 17, 2017].

EC. (2010, May 2). First Adjustment Program for Greece. Retrieved from: http://ec.europa.eu/economy_finance/assistance_eu_ms/greek_loan_facility/index_en.htm [Accessed Sep 30, 2015].

EC. (2012, March 14). Second Adjustment Program for Greece. Retrieved from: http://ec.europa.eu/economy_finance/assistance_eu_ms/greek_loan_facility/index_en.htm[Accessed Sep 30 , 2015].

EC. (2015, August 19). Memorandum of Understanding between the European Commission Acting on Behalf of the European Stability Mechanism and the Hellenic Republic and the Bank of Greece. Retrieved from: http://ec.europa.eu/economy_finance/assistance_eu_ms/greek_loan_facility/pdf/01_mou_20150811_en.pdf [Accessed November 25, 2015].

ECHR (European Court of Human Rights) 2014; 2009. Case of Cyprus v. Turkey (Application No. 25781/94); Case of Loizidou v. Turkey, (Application No. 15318/89).

Economist. (2016a, May 21). A Textile Factory with a Difference; Israel's Atomic Angst. 419(8990), p.46.

Economist. (2016b, February 6). Erdogan's New Sultanate. 418(8975), p. 3.

Economist. (2016c, January 23). Turkey's Religious Diplomacy: Mosqued Objectives - Turkey is Sponsoring Islam Abroad to extend its Prestige and Power; “Turkey's War on the Kurds: Futile Repression - Turkey's President Must Give up Trying to Crush the Kurds. Instead, he should Reopen Peace Talks; Turkey and the Kurds: Widening the Conflict - A Campaign against the PKK Turns the Country's South-East into a War Zone. 418(8973), 45-46.

E-kathimerini. (2017, July 7). US, Greek militaries to boost bilateral ties. Retrieved from http://www.ekathimerini.com/219869/article/ekathimerini/news/us-greek-militaries-to-boost-bilateral-ties [Accessed January 13, 2018].

EP \& C. (European Parliament \& Council). (2009, August 20). Directive 2009/81/EC of the European Parliament and of the Council of 13 July 2009, Section 3, Articles 11-13. Official Journal of the European Union. Retrieved from http://eur-lex.europa.eu/legal-content/EN/TXT/HTML/?uri=CELEX:32009L0081\&from=EN [Accessed May 24, 2016].

Freier, N. (2010). The New Theology: Building Partner Capacity. Small Wars Journal, 1-3. Retrieved from: http://smallwarsjournal.com/blog/journal/docs-temp/445-freier.pdf, [Accessed March 1, 2016].

FY 2018. (2017). Congressional Budget Justification-Department of State, Foreign Operations, and Related Programs. Retrieved from https://www.state.gov/s/d/rm/rls/ebs/2018/pdf/index.htm [Accessed January 13, 2018].

Gall, C., \& Higgins, A. (2017, September 12) Turkey signs Russian missile deal, pivoting from NATO. New York Times. Retrieved from https://www.nytimes.com/2017/09/12/world/europe/turkey-russia-missile-deal.html [Accessed January 4, 2018].

Galvin, T. P. (2014). Military Preparedness. Faculty Paper, Carlisle, PA: Department of Command, Leadership, and Management, $3 . \quad$ Retrieved from: http://www.strategicstudiesinstitute.army.mil/PDFfiles/PCorner/MilitaryPreparedness.pdf [Accessed May 24, 2016]. 
Gates, \& Robert, M. (2010), Helping Others Defend Themselves, Foreign Affairs, 89(4), May/June, 2-6, http://www.foreignaffairs.com/articles/66224/robert-mgates/helping-others-defend-themselves [Accessed January 12, 2018].

Grigoriadis, I. N. (2012). The Unripe Fruits of Rapprochement: Greek-Turkish Relations in the Post-Helsinki Era. International Journal, 67(1), 119-133. https://doi.org/10.1177/002070201206700109

Grigoriadis, I. N. (2015, July). From 'Central Power' to Splendid Isolation': Turkish Foreign Policy's Declining Ambitions. Working Paper, Bilkent University/ELIAMEP, The Middle East Research Project.Retrieved from: http://www.eliamep.gr/wp-content/uploads/2015/08/67_2015_-WORKING-PAPER-_Ioannis-Grigoriadis.pdf [Accessed May 27, 2016].

HNDGS (Hellenic National Defence General Staff). (2018). Violations. Retrieved from: http://www.geetha.mil.gr/en/violations-en.html [Accessed January 13, 2018].

Howorth, J. (2013). Libya and Afghanistan: The future of the Euro - U.S. security Cooperation. Yale Journal of International Affairs. Retrieved from http://heinonline.org/HOL/LandingPage?handle=hein.journals/yaljoina8\&div=9\&id=\&page $=[$ Accessed January $10,2018]$.

IHS Jane's. (2015, December 8). Turkey, Procurement. Jane’s Sentinel Security Assessment - Eastern Mediterranean. London.

IISS (The International Institute for Strategic Studies). (2017). The Military Balance: The Annual Assessment of Global Military Capabilities and Defense Economics 2017.James Hackett (Eds). London: Routledge, p. 120-123, 166-169.

Itani, F., \& Stein, A. (2016, May). Turkey's Syria Predicament. Atlantic Council, Rafik Hariri Center for the Middle East. Retrieved from http://www.atlanticcouncil.org/publications/issue-briefs/turkey-s-syria-predicament [Accessed May 27, 2016].

Jerusalem Post. (2015, May 7). Israel Holds Naval Drill with U.S. and Greece. Retrieved from http://www.jpost.com/Israel-News/Israel-holds-naval-drill-with-US-Greece-402343 [Accessed November 10, 2015].

Jones, J. L. (2014, July). All Elements of National Power - Moving Toward a New Interagency Balance for US Global Engagement. Atlantic Council. Washington, DC. Retrieved from http://www.atlanticcouncil.org/images/publications/All_Elements_of_National_Power.pdf [Accessed September $15,2015]$.

JP Updates. (2015, May 19). Israel Participates in Joint Exercise in Greece Against Iran's S-300 Missiles. Retrieved from

http://jpupdates.com/2015/05/19/israel-participates-in-joint-air-exercise-in-greece-against-irans-s-300-missiles/ [Accessed November 10, 2015].

Kariotis, T. C. (2007). A Greek exclusive economic zone in the Aegean Sea. Mediterranean Quarterly, 18(3), 56-71. https://doi.org/10.1215/10474552-2007-017

Kassimeris, C. (2008). The Inconsistency of United States Foreign Policy in the Aftermath of the Cyprus Invasion: The Turkish Arms Embargo and its Termination. Journal of Modern Greek Studies, 26(1), 91-114. https://doi.org/10.1353/mgs.0.0003

Kelly, T. K., Marquis, J. P., Thurston, C. Q., Moroney, J. D. P., \& Lynch, C. (2010). Security Cooperation Organizations in the Country Team Options for Success. RAND corporation. Retrieved from https://www.rand.org/content/dam/rand/pubs/technical_reports/2010/RAND_TR734.sum.pdf [Accessed January 11, 2018).

Kitsantonis, N. (2017, December 7). Erdogan, on Landmark Visit to Greece, Sets Diplomacy Aside, The New York Times. Retrieved from https://www.nytimes.com/2017/12/07/world/europe/erdogan-greece-turkey-visit.html [Accessed December 27, 2017].

Knomad. (2017). Migration. Retrieved from http://www.knomad.org/data/migration/emigration [Accessed January 14, 2018].

Kollias, C., \& Rafailidis, A. (2003). A Survey of the Greek Defense Industry. Defense and Peace Economics, 14(4), 320. https://doi.org/10.1080/10242690302927

Laipson, E. (1985, April 10). The Seven-Ten Ratio in Military Aid to Greece and Turkey: A Congressional Tradition. U.S. Congressional Research Service, Washington, D.C. 
Markezinis, V. (2011). Greece of Crises: A Personal Statement. Athens: Livanis, p. 389-391. [in Greek].

Mathiopoulos, M. (2017, December 4). Greece can become the energy gateway to all Europe. Handelsblatt Global. Retrieved from https://global.handelsblatt.com/opinion/greece-can-become-the-energy-gateway-to-all-europe-860653 [Accessed January 14, 2018].

McInnis, K., \& Lucas, N. (2015, December 18). What is “Building Partner Capacity?" Issues for Congress. Washington, DC: U.S. Library of Congress, Congressional Research Service. Retrieved from https://www.hsdl.org/?view\&did=789241, [Accessed March 1, 2016].

Metz, H. C. (Eds) (1990) Israel: a Country Study, (3d ed.). Washington, DC: Federal Research Division, Library of Congress, 313-323.

Michaels, D. (2016, November 29). Manufacturers Take a Page From Mother Nature: Advances in computing power, 3-D printing allow designers to save weight, cut waste with biological forms. The Wall Street Journal. Retrieved from http://www.wsj.com/articles/manufacturers-take-a-page-from-mother-nature-1480420802 [Accessed November 29, 2016].

Mix, D. E. (2013). The European Union: Foreign and Security Policy. Washington, DC: U.S. Library of Congress, Congressional Research Service.

Nation, C. R. (2003). Greece, Turkey, Cyprus, in War in the Balkans, 1991-2002, U.S. Army War College, 279-324. Retrieved from http://www.strategicstudiesinstitute.army.mil/pdffiles/00117.pdf [Accessed April 29, 2016].

NATO (North Atlantic Treaty Organization). (2017, June 29). PR/CP (2017)111. Defense Expenditure of NATO Countries (2010-2017). Retrieved from https://www.nato.int/cps/en/natohq/news_145409.htm [Accessed January 13, 2018].

NATO. (2016, July 4). Press Release 116: Defense Expenditure of NATO Countries [2009-2016]. Retrieved from http://www.nato.int/cps/en/natohq/news_132934.htm. [Accessed March 1, 2017].

Nedos, V. (2017, February 28). Souda Bay US Naval 'best in the Med.' e-kathimerini. Retrieved from http://www.ekathimerini.com/216484/article/ekathimerini/news/souda-bay-us-naval-base-best-in-the-med [Accessed January 14, 2018].

Neumann, R. E. (2015, Summer). Demystifying the Interagency Process and Explaining the Ambassador's Role. Interagency Journal, 6(3). $\quad$ Retrieved from http://thesimonscenter.org/wp-content/uploads/2015/07/IAJ-6-3-Summer-2015.pdf [Accessed October 27, 2015].

Noack, R. (2018, January 11). Seizure of 'swimming bomb' highlights Greece's growing role in the fight against smuggling. The Washington Post. Them https://www.washingtonpost.com/news/worldviews/wp/2018/01/11/seizure-of-swimming-bomb-highlights-greeces -growing-role-in-the-fight-against-smuggling/?utm_term=.9f73cc2de002 [Accessed January 13].

NSS. (2017, December). National Security Strategy of the Unites States of America. Retrieved from https://www.whitehouse.gov/wp-content/uploads/2017/12/NSS-Final-12-18-2017-0905.pdf [Accessed January 13, 2018].

NTI (Nuclear Threat Initiative). (2015, July 30). Israel Submarine Capabilities.Retrieved from http://www.nti.org/analysis/articles/israel-submarine-capabilities/ [Accessed May 25, 2016].

Nye, J. S. J. (2008, March). Theorizing Public Diplomacy: Public Diplomacy and Soft Power. The Annals of the American Academy of Political and Social Science. Available at: http://www.lexisnexis.com [Accessed December 30, 2016].

O’ Neil, S. K. (2013, June 18). Refocusing U.S.-Mexico Security Cooperation Prepared statement. Council on foreign Relations. $\quad$ Retrieved from https://www.files.ethz.ch/isn/165637/Congressional\%20Testimony\%20-\%20ONeil\%20June\%202013.pdf [Accessed January 15, 2018].

Ogorkiewicz, R. (2015). Tanks: 100 Years of Evolution. Osprey Publishing: Oxford, UK.

Ozkan, B. (2016, February 2). The West Must Stop Giving Turkey a Free Pass. The New York Times. Retrieved from http://www.nytimes.com/2016/02/03/opinion/the-west-must-stop-giving-turkeya-free-pass.html?ref=world [Accessed February 2, 2016].

Panetta, L. E. (2012, June 28). Dean Acheson Lecture: "Building Partnership in the 21st Century," U.S. Institute of Peace. YouTube, streaming video, 13:13. Retrieved from http://www.youtube.com/watch?v=rvAJi_cJnjk [Accessed 
September 15, 2015].

Perris, A. (2015, June). Foreign Markets of Defense Equipment - Foreign Military Assistance and the Development of Domestic Defense Industry: National Security, National Economy and Political Choices - The Greek Case. Personal Thesis, Hellenic Armed Forces National Defense School, Athens, Greece, p. 16-23 (in Greek).

Ploumis, M. (2016). Hellenic national security: the Turkish challenge. Army War College Review, 2(3), 21-42.

Ploumis, M. (2017). Hellenic Defence Industrial Base in the Era of Economic Crisis. South-Eastern Europe Journal of Economics, 103-125. Retrieved from http://www.asecu.gr/Seeje/issue29.html [Accessed January 2, 2018].

Ploumis, M., \& Pilalis, L. (2016). A New Deal for the Middle East and North Africa, Mediterranean Quarterly, 27(2), 89-100. https://doi.org/10.1215/10474552-3618083

PPD 23. (2013). Presidential Policy Directive 23: U.S. Security Sector Assistance Policy. Retrieved from https://www.hsdl.org/?abstract\&did=747214 [Accessed January 13, 2018].

Reuters. (2016, May 3). Exclusive: Differences Over Missile Defense, Fine Print Snag U.S.-Israel Aid Deal. Reuters, The New York Times. Retrieved http://www.nytimes.com/reuters/2016/05/03/world/middleeast/03reuters-usa-israel-defence-exclusive.html?ref=wo rld\&_r=2[Accessed May 3, 2016].

Reveron, D. S. (2016). Exporting security: International engagement, security cooperation, and the changing face of the US military ( ${ }^{\text {nd }}$ ed.). Washington DC: Georgetown University Press, p..xv.

Rossides, E. T. (2002). American Foreign Policy Regarding Cyprus and the Rule of Law, in The United States \& Cyprus: Double Standards and the Rule of Law. Washington, DC: American Hellenic Institute Foundation.

Roubatis, Y. P. (1987). Tangled Webs: The U.S. in Greece 1947-1967. Pella Publishing Company, New York, 71-72.

Sandler, T., \& Hartley, K. (1999). The Political Economy of NATO: Past, Present, Into the $21^{\text {st }}$ Century. Cambridge: Cambridge University Press, 25-26. https://doi.org/10.1017/CBO9781139175067

Satake T., \& Ishihara, Y. (2012). America's Rebalance to Asia and its Implications for Japan-US-Australia Security Cooperation. Asia-Pacific Review, 19(2), 6-25. https://doi.org/10.1080/13439006.2012.740307

Shafak, E. (2017, September 19). Turkey's future is moving backward. New York Times. Retrieved from https://www.nytimes.com/2017/09/19/opinion/turkey-islamism.html [Accessed January 3, 2018].

Shlapak, D. A., \& Johnson, M. W. (2016). Reinforcing Deterrence on NATO's Eastern Flank: War gaming the Defense of the Baltics. RAND Corporation. https://doi.org/10.7249/RR1253

SIPRI (Stockholm International Peace Research Institute). (2015). SIPRI Top 100 and Recent Trends in the Arms Industry. Retrieved from http://www.sipri.org/research/armaments/production/recent-trends-in-arms-industry[Accessed May 25, 2016].

SMoU. (2017, July 5). Supplemental Memorandum of Understanding: Greece. Retrieved from https://ec.europa.eu/info/business-economy-euro/economic-and-fiscal-policy-coordination/eu-financial-assistance/ which-eu-countries-have-received-assistance/financial-assistance-greece_en\#economicadjustmentprogrammes [Accessed August 15, 2017].

Stearns, M. (1992). Entangled Allies: U.S. Policy toward Greece, Turkey and Cyprus. Council of Foreign Relations, New York, 40-50.

Stein, A. (2014). Turkey's New Foreign Policy: Davutoğlu, the AKP and the Pursuit of Regional Order. Royal United Services Institute for Defense and Security Studies (RUSI) Whitehall Paper Series no. 83, Abingdon: Routledge Journals, 83-95.

Stoltenberg, J. (2016, February 23). Remarks by NATO Secretary General Jens Stoltenberg at the European Parliament Committee on Foreign Affairs and its Subcommittee on Security and Defense. Retrieved from http://www.nato.int/cps/en/natohq/opinions_128311.htm?selectedLocale=en[Accessed March 5, 2016].

Strassler, B., Robert. [eds.] (1996). The Landmark Thucydides: A Comprehensive Guide to the Peloponnesian War, New York: The Free Press, [5.89], 352.

The Guardian. (2016, May 5). Turkish PM Davutoglu Resigns as President Erdogan Tighten Grip. Retrieved from http://www.theguardian.com/world/2016/may/05/ahmet-davutoglus-future-turkish-prime-minister-balance [Accessed May 6, 2016].

Tickner, A. B. (2014). Colombia, the United States, and Security Cooperation by Proxy.Washington Office of Latin America. Retrieved from https://www.wola.org/files/140318ti.pdf [Accessed January 2018]. 
To Vima. (2016, April 14). Chief of HNDGS Activates Rapid Reaction Force and Air Defense. Retrieved from http://www.tovima.gr/en/article/?aid=792507 [Accessed April 30, 2016].

Trofimov, Y. (2016, February 4). West Ponders another Libya Intervention: As Islamic State Gains Ground, Europe and the U.S. Prepare for Military Action. The Wall Street Journal. Retrieved from http://www.wsj.com/articles/west-ponders-another-libya-intervention-1454606312. [Accessed February 7, 2016].

Tzanetakis, I. (2014, April 1). Exclusive Economic Zones in the Eastern Mediterranean: Risks of Conflict. Strategic Research Project, Carlisle Barracks, PA: U.S. Army War College.

U.S. DOS. (2016b, March 28). The United States Provides an Additional \$20 Million in Response to Europe Refugee and Migration Crisis. Retrieved from http://www.state.gov/r/pa/prs/ps/2016/03/255212.htm [Accessed May 7, 2016].

U.S. DOS. (2016c, February 9). Congressional Budget Justification Department of State, Foreign Operations, and Related Programs: Fiscal Year 2017, p. 190. Retrieved from http://www.state.gov/documents/organization/252179.pdf [Accessed May 24, 2016].

U.S. DOS. (Department of State) (2016a, March 2016). U.S. Relations with Greece. Retrieved from http://www.state.gov/r/pa/ei/bgn/3395.htm [Accessed May 6, 2016)].

Valmas, T. L. (2013, July 29). Greece foster Closer Co-operation with U.S. Jane’s Defense Weekly.

Valmas, T. L. (2014a, February 3). U.S. Approves Transfers of More M113 APCs to Greece. Jane's Defence Weekly.

Valmas, T. L. (2014b, March 19).Greece to Conduct Bulgarian Air Policing. Jane's Defence Weekly.

Valmas, T. L. (2015, November 30). Greece funds CH-47D buy. Jane's Defence Weekly.

Vrbensky, R. (2009, February). Can Development Prevent Conflict? Integrated Area-Based Development in the Western Balkans. Conflict Security \& Development, 9(1), 75-110. https://doi.org/10.1080/14678800802704929

Wall Street Journal. (2017, August 11). An Aussie Terror Warning Islamic State came close to taking down a passenger plane. Retrieved from https://www.wsj.com/articles/an-aussie-terror-warning-1502406828. [Accessed August 14, 2017].

Weaver, M. (2016, January 14). Turkey: Chomsky Hits Back at Erdoğan, Accusing him of double Standards on Terrorism. The Guardian. Retrieved from http://www.theguardian.com/us-news/2016/jan/14/chomsky-hits-back-erdogan-double-standards-terrorism-bomb-i stanbul . [Accessed March 7, 2016].

Weed, M. C. et al. (2014, March 10). U.S. Diplomatic Missions: Background and Issues on Chief of Mission (COM) Authority. Washington, DC: Congressional Research Service. Retrieved from https://www.hsdl.org/?view\&did=751906[Accessed October 27, 2015].

White, T. P. (2014). Security Cooperation: How it All Fits. Joint Force Quarterly 72 (1 ${ }^{\text {st }}$ Quarter), 106-108. ). Retrieved from http://ndupress.ndu.edu/Media/News/NewsArticleView/tabid/7849/Article/577493/jfq-72-security-cooperation-ho w-it-all-fits.aspx, [Accessed March 1, 2016].

\section{Copyrights}

Copyright for this article is retained by the author(s), with first publication rights granted to the journal.

This is an open-access article distributed under the terms and conditions of the Creative Commons Attribution license which permits unrestricted use, distribution, and reproduction in any medium, provided the original work is properly cited. 